\title{
Does the PGC-1/PPAR $\gamma$ pathway play a role in Com-1/p8 mediated cell growth inhibition in prostate cancer?
}

\author{
WEN G. JIANG ${ }^{1}$, GAYNOR DAVIES ${ }^{1}$, HOWARD KYNASTON ${ }^{1}$, \\ MALCOLM D. MASON ${ }^{2}$ and OYSTEIN FODSTAD ${ }^{3,4}$

\begin{abstract}
${ }^{1}$ Metastasis and Angiogenesis Research Group, ${ }^{2}$ Clinical Oncology, Cardiff University School of Medicine, Cardiff, UK; ${ }^{3}$ Cancer Research Institute, University of South Alabama, Mobile, AL, USA; ${ }^{4}$ Institute for Cancer Research, Rikshospitalet-Radiumhospitalet Medical Center, and Faculty of Medicine, University of Oslo, Oslo, Norway
\end{abstract}

Received May 17, 2006; Accepted July 14, 2006

\begin{abstract}
Com-1, candidate of metastasis-1, also known as $\mathrm{p} 8$, has been shown to regulate the growth and apoptosis of cancer cells and is associated with the disease progression in human cancers including prostate cancer. In the current study, we investigated a potential mechanism underlying the anticancer action of Com-1/p8 in human prostate cancer. Human prostate cancer cells were used. Full-length Com-1 cDNA was isolated from normal mammary tissues. Ribozyme transgenes that specifically target human Com-1 were constructed using the pEF6/V5-His vector. Com-1 interacting proteins were determined using immunoprecipitation method. Cell growth and invasiveness were investigated using in vitro methods. Using immunoprecipitation and Western blotting, Com-1 was found to be cross-reprecipitated with PGC-1, a coactivator of peroxisome proliferator activated receptor (PPAR)- $\gamma$, but not PPAR $-\gamma$ itself. Elimination of Com-1 from prostate cancer cells resulted in a reduced response of the cells to ciglitizone, a PPAR- $\gamma$ agonist, whereas forced expression of Com-1 rendered cells more responsive to ciglitizone. We further demonstrated that the overexpression of Com-1/p8 resulted in changes in the expression of the PGC-1 responsive gene, fatty acid synthase (FAS). Com-1 may act as a tumour suppressor in human prostate cancer cells. The potential tumour suppressive effect of Com-1 is at least partly via its interaction with PGC-1, the PPAR- $\gamma$ coactivator.
\end{abstract}

\section{Introduction}

Com-1, candidate of metastasis-1, otherwise known as p8, which was discovered from metastatic breast tumours of nude rats, has been under active investigation in recent years.

Correspondence to: Professor Wen G. Jiang, Metastasis and Angiogenesis Research Group, Cardiff University School of Medicine, Heath Park, Cardiff CF14 4XN, UK

E-mail: jiangw@cf.ac.uk

Key words: Com-1, p8, prostate cancer, PPAR $\gamma$, PGC-1, ciglitizone
Although initially thought to play a role in promoting metastasis and to have some degree of mitogenic activity $(1,2)$, subsequent investigations have shown that the molecule appears to play a more diverse role in cancer, depending on the cell function and tumour type. In thyroid cancer (3), in fibroblasts (4), and in pancreatic cancer $(5,6)$, Com- 1 appears to be associated with the aggressiveness of the tumour cells. However, in other tumour types, Com-1 has a different expression pattern. In breast cancer cells, Com-1 is associated with 1,25-Dihydroxyvitamin D3 induced growth inhibition which coincides with a rise of Com-1 (7). In clinical breast cancer, low levels of Com-1 transcript are associated with a poor clinical outcome of the patients (8). In pancreatic cancer, the overexpression of Com-1/ p8 by transfection resulted in growth inhibition (9), and p8-silenced cells by way of an antisense approach grew more rapidly than control cells transfected with the empty retrovirus. It has also been shown that inhibitors to MEK $1 / 2$ and JNK can upregulate $\mathrm{p} 8$ expression, and that in fibroblasts, $\mathrm{p} 8$ is a cell growth inhibitor that facilitates apoptosis induced by DNA damage (10) which may involve p53.

The p8 polypeptide is a phosphoprotein subject to constitutive degradation by the ubiquitin/proteasome system mediated by phosphatidylinositol 3-kinase and protein kinase $\mathrm{B} / \mathrm{Akt}$. By contrast, stabilization of the $\mathrm{p} 8$ protein requires glycogen synthase kinase-3 (11). Garcia-Montero et al (12) have shown that TGF- $3-1$ can activate Com-1/p8 expression, which in turn enhances the Smas-transactivation in the TGF$\beta$ pathway. Com $-1 / \mathrm{p} 8$ is primarily a nuclear protein and has been suggested to possibly be involved in the p27kip1 and p21cip1 pathway. We have recently shown that Com-1 interacts with ER- $\beta$ and counteracts oestrogen-mediated effects on breast cancer cells (13).

Here we report the potential interaction between Com-1 and the peroxisome proliferator-activated receptor $-\gamma$ coactivator-1 (PGC-1). The human transcriptional coactivator PPAR $-\gamma$ coactivator $-1 \alpha$ (PGC- $1 \alpha)$, indentified from a human cDNA library in a steroid-responsive yeast strain $(14,15)$, has been characterized as a tissue-specific coactivator that enhances the activity of many nuclear receptors, coordinates transcriptional programs important for energy metabolism and 
acts as a broad regulator of cellular energy metabolism. The orphan nuclear receptor estrogen-related receptor $\alpha(\mathrm{ERR}-\alpha)$ was identified in a yeast two-hybrid screen of a cardiac cDNA library as a novel PGC- $1 \alpha$-binding protein. It has been reported that PGC1- $\alpha$ and ERR- $\alpha$ interact with each other and this interaction is distinct from that of other nuclear receptor PGC- $1 \alpha$ partners, including PPAR- $\alpha$, hepatocyte nuclear factor- $4 \alpha$ and estrogen receptor $\alpha$. Thus, ERR- $\alpha$ and ERR $-\gamma$ are novel PGC- $1 \alpha$ interacting proteins. It would also appear that PGC-1 $\alpha$ selectively binds transcription factor partners in the regulation of energy metabolism (16). Few responsive genes are known to PGC-1, including Farnenoid X receptor (FxR), nucleus receptors $(\mathrm{NrF} 1)$ and fatty acid synthase (FAS) $(17,18)$.

Following our recent study which revealed a reduction of Com-1 in prostate tumours and that Com-1 may act as a tumour suppressor using in vitro and in vivo models with prostate cancer (19), we examine the potential role of the PPAR- $\gamma$ and PGC-1 pathway in the action of Com-1 in prostate cancer cells and report that in prostate cancer cells interaction between Com-1/p8 and PGC-1 represents a novel mechanism for the action of Com-1.

\section{Materials and methods}

Materials. Human prostate cancer cell lines PC-3, DU-145, CA-HPV-10 and LN-Cap were obtained from ATCC (American Type Cell Culture, Rockville, MD). RNA extraction and RT kits were obtained from AbGene Ltd. (Surrey, UK). PCR primers were designed using Beacon Designer (Palo Alto, CA) and synthesised by Invitrogen Ltd. (Pasley, UK). Molecular biology grade agarose and DNA ladder were obtained from Invitrogen, and the master mix for routine PCR and quantitative PCR, AbGene. Monoclonal antibody to human PPAR- $\gamma$, polyclonal antibody to human PGC-1 and rabbit anti-human Com-1 (p8) polyclonal antibody were all purchased from Santa Cruz Biotechnology (Santa Cruz, CA, USA). Peroxidase-conjugated anti-rabbit, anti-mouse and anti-goat antibodies were from obtained from Sigma (Little Chalfont, UK) and a biotin universal staining kit, from Vector Laboratories (Nottingham, UK). Ciglitizone was purchased from Sigma Ltd.
Immunocytochemical staining of Com-1. Cancer cells were fixed with $4 \%$ formaldehyde and permeabilised with $0.1 \%$ Triton-X100. After blocking with $10 \%$ milk, primary antibodies (1:150 dilution from stock) were added to the cells for $1 \mathrm{~h}$, followed by extensive washing. Respective HRPconjugated secondary antibody was then added for $1 \mathrm{~h}$, followed by extensive washing and DAB for colour development. Cells were then photographed using a digital camera, for evaluation of cytoplasmic and nuclear staining. The slides were then submerged overnight in xylene to remove the cover slips, followed by descending grades of ethanol washing. The slides were then counterstained with hematoxylin and remounted for photographing and presentation. Images from non-counterstained slides were processed using Optimas software (Optimas, Bothell, WA, USA). The staining intensity was determined using a method previously described (20), where between 50-80 cells of each setting were randomly analysed. Mean arbitrary intensity was calculated for the cytoplasmic and nuclear regions.

RNA extraction, cDNA synthesis and preparation of Com1/p8 knockdown and human Com-1 overexpressing cells. RNA was extracted from cells and the concentration of RNA was determined using a UV spectrophotometer. Reverse transcription was performed using a RT kit with an anchored oligo-dt primer (AbGene), using $1 \mu \mathrm{g}$ of total RNA. The quality of the cDNA was verified using $\beta$-actin primers.

The hammerhead ribozyme transgenes and Com-1 expression cassette were prepared as in previous studies $(13,19,21)$. The following stably transfected cells from PC-3, DU145 and CA-HPV-10; Com-1 knockout cells, PC3 ${ }^{\text {Acom1, }}$ DU145 ${ }^{\Delta \mathrm{com} 1}$ and CA-HPV ${ }^{\Delta c o m} 1$; Com-1 overexpressing cells, PC-3 $3^{\text {com1Exp }}$ DU145 ${ }^{\text {com1Exp }}$, and CA-HPV ${ }^{\text {com1Exp }}$; and plasmid only control cells, PC $3^{\mathrm{pEFa}}$, DU145 ${ }^{\mathrm{pEFa}}$ and CA-HPV ${ }^{\mathrm{pEFa}}$, were used together with the respective wild-types.

Immunoprecipitation and Western blotting. Cells were extracted using a lysis buffer, containing $2.4 \mathrm{mg} / \mathrm{ml}$ Tris, $4.4 \mathrm{mg} / \mathrm{ml} \mathrm{NaCl}, 5 \mathrm{mg} / \mathrm{ml}$ sodium deoxycholate, $20 \mu \mathrm{g} / \mathrm{ml}$ sodium azide, $1.5 \%$ Triton, $100 \mu \mathrm{g} / \mathrm{ml}$ PMSF, $1 \mu \mathrm{g} / \mathrm{ml}$ leupeptin, and $1 \mu \mathrm{g} / \mathrm{ml}$ aprotinin, for $30 \mathrm{~min}$. Protein concentrations were measured using fluorescamine and

Table I. PCR primers.

Sense (5'-'3)

Com-1 expression

Com-1 ribozyme- 8

Com-1 ribozyme-9

Ribozyme screening

PGC-1

PPAR- $\gamma$

FxR

$\mathrm{NrF} 1$

FAS

B-actin cetggatgaatctgacetc

atggccaccttccac

cctggatgaatctgacctc
atggccaccttccac
ctgcagcttctctcttggtgcctgatgagtccgtgagga
ctgcagctggttgctggtggctgatgagtccgtgagga
ctgatgagtccgtgaggacgaa
agtacaacaatgagccttcaa
ctatggagttcatgcttgtg
gggaactgaaaatgactcaa
atggcetctttatggcagat
tgcggcctatagggacag
gctgatttgatggagttgga

gctgatttgatggagttgga
Antisense (5'-'3)

actgaacctgaccgtacacaagcagcttctctcttggtg actgcgecgtgccectcg

actagtggaggccggaaaggtttcgtcctcacggact actagtatggccacctttttcgtcctcacggact

ttcgtcctcacggactcatcag, catcaaatgagggcaatc gtactgacatttattt

actgaacctgaccgtacatcctgaagcttctctactgc actgaacctgaccgtacaaccacagtctggtacatgct actgaacctgaccgtacagtgagctgtccaggttga tcagctacttgttcttgagtgaa 


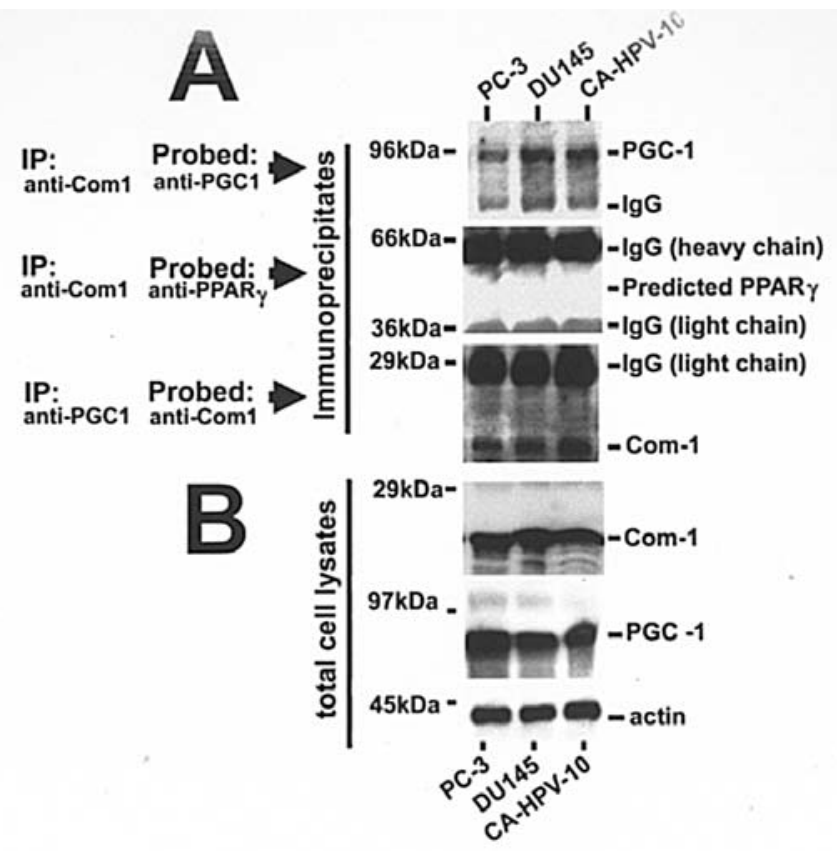

Figure 1. Interaction between Com-1 and PGC-1. (A) Cross immunoprecipitation between Com-1 and PGC-1. Cell lysates were either precipitated with anti-Com-1 (top two panels) or with anti-PGC-1 antibody. The precipitates were separated on either SDS-PAGE (top two panels) or Tricine-PAGE (bottom panel) and probed with the respective antibodies. Com-1 and PGC-1 cross-precipitated with each other, however, no interaction was seen between PPAR- $\gamma$ and Com-1. (B) Expression of all three proteins in prostate cancer cell lines.

quantified by using a multi-fluoroscanner (Denly, Sussex, UK). The samples were then boiled at $100^{\circ} \mathrm{C}$ for 5 min before clarification at $13,000 \mathrm{~g}$ for $10 \mathrm{~min}$. Equal amounts of protein from each cell sample (controls and treated) were added to an $8 \%$ poly-acrylamide gel. For immunoprecipitation, prostate cancer cells were pelleted and lysed in the same buffer with $1 \mathrm{mM}$ sodium orthovandate. Anti-Com-1/p8 (80 $\mu \mathrm{g})$ or antiPGC-1 antibody was added to equal amounts of protein for $1 \mathrm{~h}$ with constant agitation, followed by the addition of protein $\mathrm{A} / \mathrm{G}$ agarose for an additional $1 \mathrm{~h}$ and washing with the same lysis buffer. The immunoprecipitate was solubilised with a sample buffer that contained 5\% 2-mercaptolethanol. The samples were then separated on $10 \%$ SDS-PAGE or $12.5 \%$ Tris-Tricine PAGE (for Com-1 only). Protein blots were probed with a panel of antibodies $(n=64)$ from a pool of antibodies in our laboratories, followed by washing and subsequent probing with appropriate peroxidase-conjugated secondary antibodies. Protein bands were visualised with a chemiluminescence (ECL) kit.

In vitro cell growth assay. This was modified from a previously described method (22). Cells were plated into a 96well plate at 2,500 cells/well, with or without treatment with 1ciglitizone (0.1-100 $\mu \mathrm{M}$ final concentration). Cells were fixed in $10 \%$ formaldehyde at the day of plating and daily for 6 subsequent days after plating, and then stained with $0.5 \%$ (w/v) crystal violet. Following washing, the stained crystal was extracted with $10 \%(\mathrm{v} / \mathrm{v})$ acetic acid and the absorbance was determined using a multiplate reader. The growth of cells are shown in this study as percentage of the respective untreated cells at a given day.

\section{Results}

Interaction of Com-1 with PGC-1, a PPAR- $\gamma$ coactivator. To identify the potential binding partners of Com-1, we first used immunoprecipitated proteins that intereacted with Com-1, using the anti-Com-1 antibody for immunoprecitation. The precipitates were subsequently separated on multiple gels and blots probed with a panel of 64 antibodies that recognise potential nuclear as well as other proteins. From the panel, PGC-1, but not PPAR- $\gamma$, was one of the few proteins that coprecipitated with Com-1 (Fig. 1). Using reverse precipitation, precipitation with anti-PGC-1 antibody and probing with anti-Com-1 antibody, the interaction between the two proteins was verified (Fig. 1).

Modification of Com-1 expression results in differential growth response to PPAR $-\gamma$. To test if Com-1 is involved in PPAR- $\gamma /$ PGC- 1 mediated cell growth inhibition in response to the PPAR- $\gamma$ agonist, we first generated a panel of genetically modified (GM) prostate cancer cell lines, whose expression of Com-1 was either knocked down by ribozymes or increased by forced expression (Fig. 2) (19).

The effects of ciglitizone on the growth of these cells were evaluated. Ciglitizone inhibited cell growth over a range of concentrations (Fig. 3, open circles). However, Com-1 knockout prostate cancer cells had reduced sensitivity,
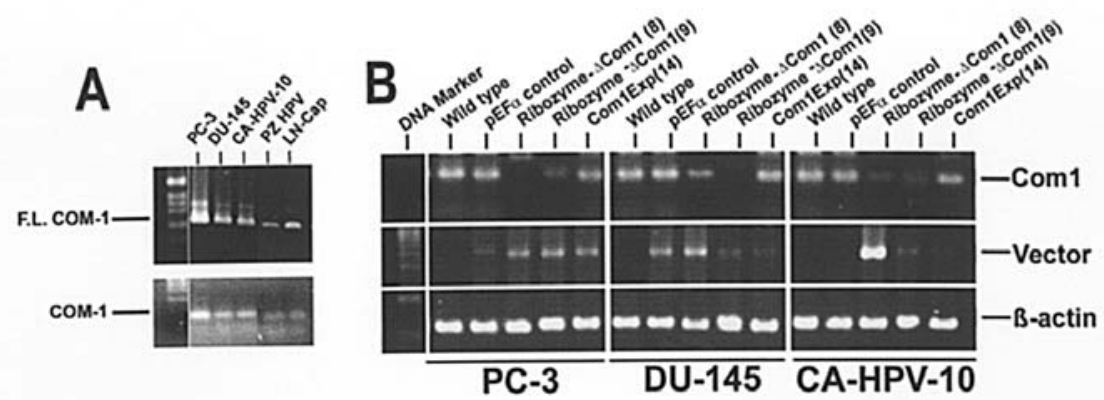

Figure 2. Expression of Com-1 in prostate cancer cells (A) and genetic manipulation (B). All five prostate cancer cell lines expressed Com-1 mRNA (F.L. Com-1, full-length Com-1; bottom panel in A, amplified internal region of Com-1). Two ribozyme transgenes had knockdown expression of Com-1 mRNA from all three prostate cancer cells (B).( adapted from ref. 19.) 

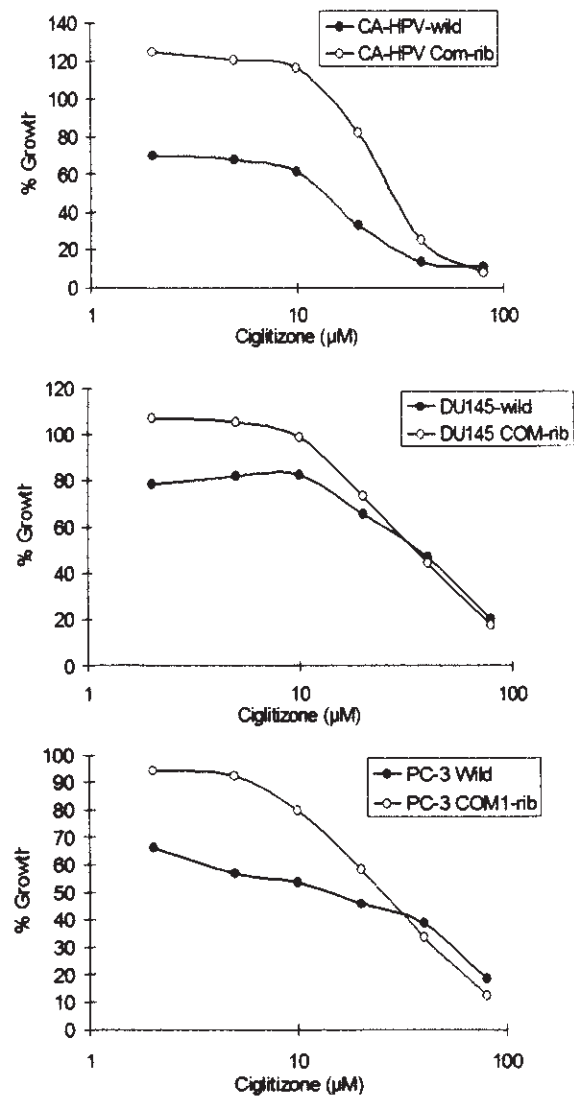

Figure 3. Loss of Com-1 expression and change of cell response to ciglitizone. Shown are representative responses from three prostate cancer cells with which their expression of Com-1 was knocked down by Com-1 ribozyme transgene (Com1-rib). Shown are percentages of cell growth over a 5-day period. Top, CA-HPV cells; middle, DU145 cells; bottom, PC-3 cells.

although not completely, to the growth inhibition of ciglitizone (Fig. 3, solid circles). Fig. 3 shows the cell response on day 5. Data for all the respective cells including wild-type, control plasmid-transfected, ribozyme-transgene transfected and expression vector-transfected cells are summarised in Table II.
We further treated the aforementioned GM cells with ciglitizone, an agonist to PPAR- $\gamma$. As shown in Fig. 4 (top panel), ciglitizone increased the Com-1 protein levels in both wild-type PC-3 and PC $3^{\mathrm{PEFa}}$ as shown in Western blotting. However, the agonist had no marked effect on PGC-1 expression.

We further analysed the cellular and nuclear staining of Com-1, PGC-1 and PPAR- $\gamma$ using immunocytochemistry (ICC) and Western blotting.(WB). As shown in Fig. 4, treatment of wild-type PC-3 cells seems to only marginally increase the amount of Com-1 (Fig. 4: top, WB; bottom panel, ICC). This marginal increase appears to be in the nuclear fraction.

Modification of Com-1 expression and results in changes of $P G C-1$ responsive genes. To assess if the manipulation of Com-1 has an impact on the responsive genes of PGC-1, we evaluated the expression of FAS, FxR and $\mathrm{NrF1}$, which are known PGC-1 responsive genes. We evaluated these gene products in Com-1 modified cells, PC $3^{\Delta c o m 1}$, DU145 1 com1 CA-HPV ${ }^{\Delta \mathrm{com} 1}$, Com-1 overexpressing cells, PC-3 $3^{\text {com1Exp, }}$ DU145 ${ }^{\text {comlExp }}$, and CA-HPV ${ }^{\text {comlExp }}$, plasmid only control cells, PC $3^{\mathrm{pEFa}}, \mathrm{DU} 145^{\mathrm{pEFa}}$ and CA-HPV ${ }^{\mathrm{pEFa}}$, used together with the respective wild-types. The overexpression of Com-1 rendered cells to express lower levels of FAS, but not FxR and NrF1, compared with wild-type and transfection control cells (Fig. 5).

\section{Discussion}

Com-1 interacts with PGC-1, but not PPAR- $\gamma$. We conducted a co-precipitation test using a panel of antibodies, and found that the peroxisome proliferator-activated receptor- $\gamma$ $(\operatorname{PPAR} \gamma)$ coactivator-1, PGC-1, is one of the few proteins that co-precipitated with Com-1. The human transcriptional coactivator PPAR- $\gamma$ coactivator- $1 \alpha($ PGC- $1 \alpha)$, identified from a human cDNA library in a steroid-responsive yeast strain $(16,17)$, has been characterized as a tissue-specific coactivator that enhances the activity of many nuclear

Table II. Com-1 expression and ciglitizone-regulated cell growth (72 h).

\begin{tabular}{|c|c|c|c|c|}
\hline \multirow[t]{2}{*}{ Cell line } & \multirow[t]{2}{*}{ Variant } & \multicolumn{3}{|c|}{ Growth (\%) } \\
\hline & & $1 \mu \mathrm{M}$ & $5 \mu \mathrm{M}$ & $20 \mu \mathrm{M}$ \\
\hline \multirow[t]{4}{*}{ PC-3 } & Wild-type & 93.3 & 93.3 & 56.4 \\
\hline & $\mathrm{pEFa}$ control & 91.7 & 89.9 & 60.2 \\
\hline & Com1Rib & 138.2 & 101.6 & 63.9 \\
\hline & Com1Exp & 108.8 & 80.7 & 40.0 \\
\hline \multirow[t]{4}{*}{ DU-145 } & Wild-type & 92.0 & 96.9 & 85.9 \\
\hline & $\mathrm{pEFa}$ control & 94.1 & 98.4 & 87.2 \\
\hline & Com1Rib & 107.0 & 97.9 & 90.4 \\
\hline & Com1Exp & 92.7 & 88.6 & 41.9 \\
\hline \multirow[t]{4}{*}{ CA-HPV } & Wild-type & 104.2 & 105.7 & 72.79 \\
\hline & $\mathrm{pEFa}$ control & 108.3 & 101.7 & 93.3 \\
\hline & Com1Rib & 102.8 & 100.6 & 96.6 \\
\hline & Com1Exp & 98.1 & 70.2 & 37.6 \\
\hline
\end{tabular}



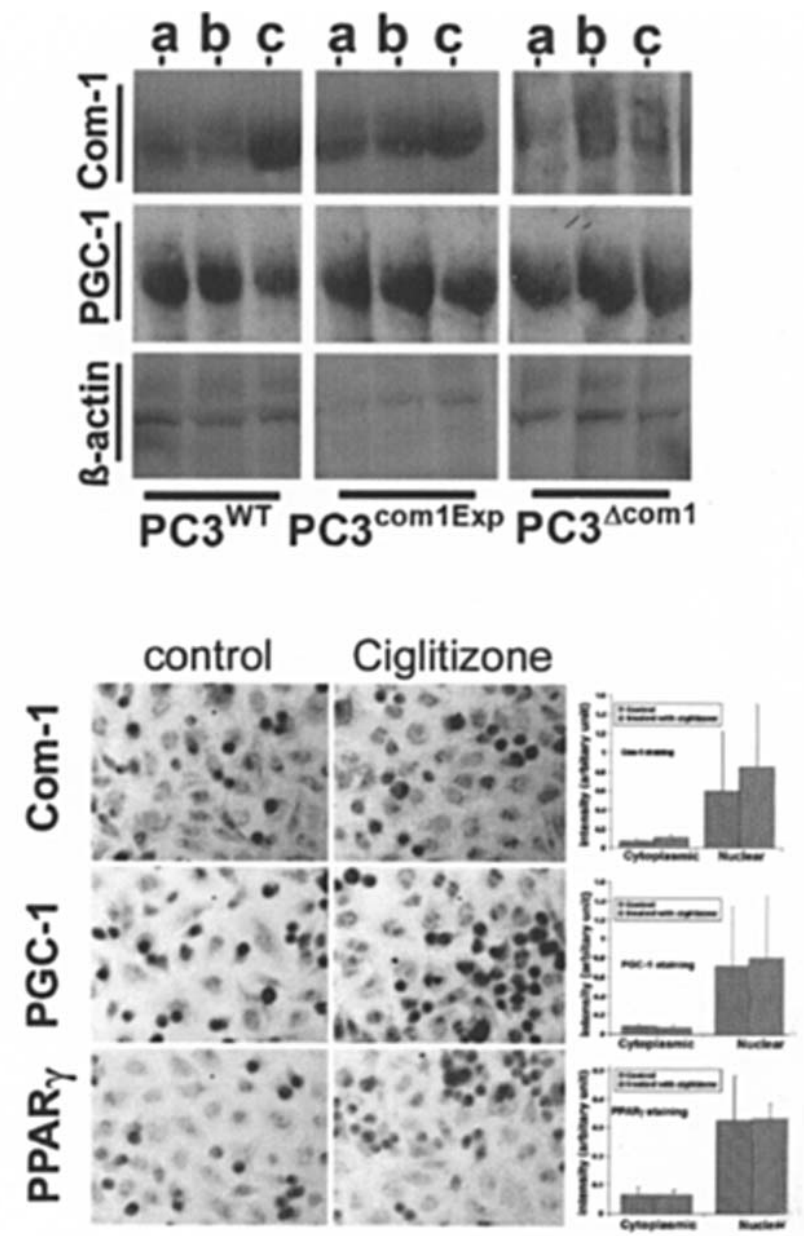

Figure 4. Effects of ciglitizone on protein expression of Com-1 and PGC-1 in PC-3 cells. Top: cells were treated with (a) medium,(b) medium with $1 \%$ DMSO and (c) ciglitizone $(5 \mu \mathrm{M})$. Increased levels of Com-1 were seen with wild-type and transfection control cells, but not in Com-1 knockdown cells (top panel). Changes in PGC-1 in these cells were not significant (middle panel). B-actin was used as a housekeeping control. Bottom, immunocytochemical staining of Com-1 in wild-type PC-3 cells following treatment with medium (left panel) or with ciglitizone ( $5 \mu \mathrm{M}$, middle panel). The changes in the staining intensity of the cells are given in the right panel.

receptors, coordinates transcriptional programs important for energy metabolism and is a broad regulator of cellular energy metabolism. PGC-1 promotes transcription through the assembly of a complex that includes the histone acetyltransferases steroid receptor coactivator-1 (SRC-1) and CREB binding protein $(\mathrm{CBP}) / \mathrm{p} 300$ (23). PGC-1 acts to coordinate the process of metabolic adaptation in the liver, by interacting with $\mathrm{HNF} 4 \alpha$ and $\mathrm{cAMP}$-response element-binding protein (CREB) (24,25). PGC-1 is a coactivator of MEF2C, a muscleselective transcription factor, and can control the level of endogenous GLUT4 gene expression in muscle (26). Few PGC-1 responsive genes are known. Farnecoid X receptor (FxR), nuclear receptor family group $\mathrm{H}$ members and fatty acid synthase are amongst the known genes $(17,18)$. The over-expression of PGC-1 can decrease the expression of fatty acid synthase. The current study has shown that the overexpression of Com-1 in prostate cancer cells also results in the reduction of fatty acid synthase expression. However, manipulating Com-1 expression has not affected the

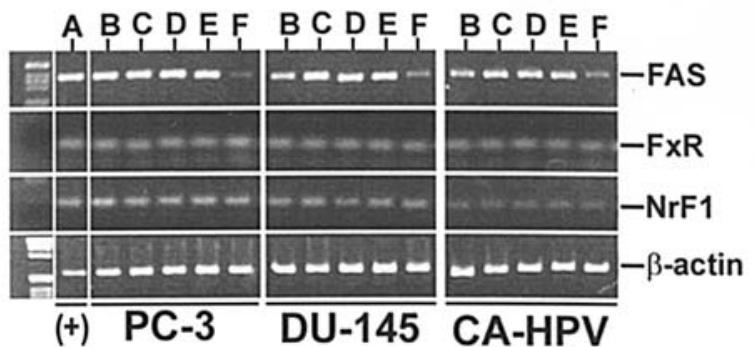

Figure 5. Expression of Com-1 and the impact on the expression of putative PGC-1 responsive genes FAS (fatty acid synthase), FxR, and $\mathrm{NrF1}$. (A) Positive control from normal human tissues, (B) wild-type cells, (C) control transfected cells (with pEFa plasmid), (D) Com-1 ribozyme transfected cell1, (E) Com-1 ribozyme transfected cell-2, and (F) cells with Com-1 forced expression.

expression of $\mathrm{NrF} 1$ and FxR. Taken together, Com-1 may operate with $\mathrm{PGC}-1$ in regulating $\mathrm{PGC}-1$ responsive genes, including fatty acid synthase.

The impact of Com-1 and $\mathrm{PGC}-1$ requires further investigation. However, PGC-1 is involved in the transcriptional regulation of the UCP1 gene in humans and mediates the effects of PPAR- $\alpha$ and PPAR- $\gamma$ agonists and retinoic acid (27) and is a coactivator for RXR $\alpha$ (28). PGC-1 has also been implicated in the cachetic response and oxidative metabolism in skeletal muscle (28-31). These collectively suggest an important role for Com-1 in the metabolic response in malignancies.

A potential role for Com-1 in the PGC-1/ER connection. PGC- 1 is a bona fide ER $\alpha$ coactivator, which may serve as a convergence point between PPAR- $\gamma$ and ER $\alpha$ signalling (32). A PGC-1 related coactivator, PERC (PGC-1 related estrogen receptor coactivator), is known to interact with the AF2 domain of ER $\alpha$ in an estrogen-dependent manner. PERC and PGC-1 show distinct preferences for enhancing ER $\alpha$ in different promoter contexts. PERC enhances the ER $\alpha$-mediated response to the partial agonist tamoxifen, while PGC-1 modestly represses it. The two coactivators are likely to mediate distinct, tissue-specific responses to estrogens (33). Akt can mediate the downregulation of peroxisome proliferatoractivated receptor (PPAR)- $\gamma$ coactivator-1 (PGC-1) and PPAR- $\alpha$ (34). Recently, we reported that Com-1 forms a complex with ER- $\beta$ in human breast cancer cells $(8,13)$. In breast cancer cells, the loss of Com-1 resulted in cells responding more vigorously to oestrogen with a rapid increase in cell growth. Vice versa, the overexpression of Com-1 in breast cancer cells resulted in the cells being less responsive to oestrogen and less invasive. We suggested that Com-1, by forming a complex with ER- $\beta$ and PGC-1, acts as a tumour suppressor in human solid tumours including prostate and breast cancers (8).

The role of Com-1 in prostate cancer cells. We and others have reported that PGC- 1 expression, together with PPAR- $\gamma$, is reduced in human cancer $(31,35)$. Furthermore, ER- $\beta$, which plays an opposite role to ER- $\alpha$ in cancer cells, has also been reported to be reduced in certain types of cancer such as breast cancer. 
Peroxisome proliferator-activated receptor- $\gamma$ (PPAR- $\gamma$ ) belongs to a nuclear hormone receptor super-family that regulates gene expression. PPAR- $\gamma$ contains DNA, lipid and $\mathrm{A} / \mathrm{B}$ binding domains that recognise DNA response elements in the promoters of their target genes and interact with lipid ligands and prostaglandins (PGJ2). Chang et al has shown that ligands of PPAR- $\gamma$ such as troglitazone, BRL49653, 15S-hydroxyeicosatetraenoic acid and 15-deoxydelta12,14prostaglandin $\mathbf{J} 2$ are capable of inducing apoptosis of cancer cells and inhibiting tumourigenesis $(36,37)$. It has also been demonstrated that PPAR- $\gamma$ forms a complex with its coactivators (PGC-1 and -2) and in association with other transcription factors such as SRC-1 and CREB binding proteins (38-40) regulates the expression of a number of target genes including the cMet protooncogene, E-cadherin and the cyclin regulator $\mathrm{p} 27^{\mathrm{Kip} 1}$. Studies by Hisitake (41) demonstrated that PPAR $-\gamma$ agonists are capable of reducing the growth and progressive activity of prostate cancer cells as well as inhibiting the transcription of genes such as cMet and HGF both of which are associated with tumour progression.

Anomalies in PPAR group members have been shown to cause tumourigenesis in both human cancers and animal models. Previous studies have shown (42) that poly-unsaturated fatty acids activate PPAR- $\gamma$ levels in cancer cells. PGC-1, as a key modulator of hepatic gluconeogenesis and as a central target of the insulin-cAMP axis in liver, regulates mitochondrial biogenesis and function $(15,43)$. The transcriptional activity of PPAR $\gamma$ may not only be decreased by mutation but also by downregulation of the coactivator PGC-1 of PPAR- $\gamma$ (44). Recently, we have also reported, for the first time, that the mRNA level of PGC- 1 is also reduced in human breast cancer and the reduction is associated with an aggressive nature of the breast tumours (35). Taken together, it is suggested that in human tumours including prostate cancer, the loss and/or reduction of PGC-1 and Com-1 in cancer cells, particularly in the nuclear fraction, may act both on the control of transcription of tumour suppressor genes and cell growth. This would allow cancer cells to gain rapid growth and aggressiveness. A few other theories have been recently reported with regards to the mechanism of Com-1regulated cell growth and death. Com-1/p8 has been shown to be one of the key modulators in the antitumour (proapoptotic) effects of the cannabinoids, and p8 mediates its apoptotic effect via upregulation of the endoplasmic reticulum stress-related genes ATF-4, CHOP, and TRB3 (45). Furthermore, the interaction between Com-1/p 8 and prothymosin $\alpha$ (ProT $\alpha)$ has been reported to be key to staurosporine-induced apoptotic response in HeLa cells (6). The interplay between Com-1, PGC-1 and ProT $\alpha$ warrants further investigation.

In conclusion, the current study has shown that Com-1/p8 is a potential tumour suppressor in human prostate cancer. One of the potential mechanisms underlying the action of Com-1 is its interaction with PGC-1. Levels of Com-1 influence cellular responses to PPAR- $\gamma$ agonists. Com- 1 may have important therapeutic implications as well as prognostic implications.

\section{Acknowledgements}

The authors thank Cancer Research Wales for supporting their work and Dr Gregory Harrison for his assistance in immunoprecipitation experiments.

\section{References}

1. Ree AH, Tvermyr M, Engebraaten O, Rooman M, Rosok O, Hovig E, Meza-Zepeda LA, Bruland OS and Fodstad O: Expression of a novel factor in human breast cancer cells with metastatic potential. Cancer Res 59: 4675-4680, 1999.

2. Soulier J, Madani A, Cacheux V, Rosenzwajg M, Sigaux F and Stern MH: The MTCP-1/c6.1B gene encodes for a cytoplasmic $8 \mathrm{kD}$ protein overexpressed in T cell leukemia bearing a $\mathrm{t}(\mathrm{X} ; 14)$ translocation. Oncogene 9: 3565-3570, 1994.

3. Ito Y, Yoshida H, Motoo Y, Miyoshi E, Iovanna JL, Tomoda C, Uruno T, Takamura Y, Miya A, Kobayashi K, Matsuzuka F, Matsuura N, Kuma K and Miyauchi A: Expression and cellular localization of $\mathrm{p} 8$ protein in thyroid neoplasms. Cancer Lett 201: 237-244, 2003.

4. Vasseur S, Hoffmeister A, Garcia-Montero A, Mallo GV, Feil R, Kuhbandner S, Dagorn JC and Iovanna JL: p8-deficient fibroblasts grow more rapidly and are more resistant to adriamycin-induced apoptosis. Oncogene 21: 1685-1694, 2002.

5. Su SB, Motoo Y, Iovanna JL, Berthezene P, Xie MJ, Mouri H, Ohtsubo K, Matsubara F and Sawabu N: Overexpression of $\mathrm{p} 8$ is inversely correlated with apoptosis in pancreatic cancer. Clin Cancer Res 7: 1320-1324, 2001

6. Su SB, Motoo Y, Iovanna JL, Xie MJ, Mouri H, Ohtsubo K, Yamaguchi Y, Watanabe H, Okai T, Matsubara F and Sawabu N: Expression of p8 in human pancreatic cancer. Clin Cancer Res 7: 309-313, 2001

7. Bratland A, Risberg K, Maelandsmo GM, Gutzkow KB, Olsen OE, Moghaddam A, Wang MY, Hansen CM, Blomhoff HK, Berg JP, Fodstad $\mathrm{O}$ and Ree AH: Expression of a novel factor, coml, is regulated by 1,25-dihydroxyvitamin D3 in breast cancer cells. Cancer Res 60: 5578-5583, 2000.

8. Jiang WG, Watkins G, Douglas-Jones A, Mokbel K, Mansel RE and Fodstad O: Expression of Com-1/p8 in human breast cancer, and its relevance to clinical outcome and ER status. Int $\mathrm{J}$ Cancer 117: 730-737, 2005.

9. Malicet C, Lesavre N, Vasseur S and Iovanna JL: p8 inhibits the growth of human pancreatic cancer cells and its expression is induced through pathways involved in growth inhibition and repressed by factors promoting cell growth. Mol Cancer 2: 37, 2003.

10. Vasseur S, Hoffmeister A, Garcia S, Bagnis C, Dagorn JC and Iovanna JL: $\mathrm{p} 8$ is critical for tumour development induced by rasV12 mutated protein and E1A oncogene. EMBO Rep 3: 165-170, 2002.

11. Goruppi S and Kyriakis JM: The pro-hypertrophic basic helixloop-helix protein $\mathrm{p} 8$ is degraded by the ubiquitin/proteasome system in a protein kinase B/Akt- and glycogen synthase kinase3-dependent manner, whereas endothelin induction of $\mathrm{p} 8$ mRNA and renal mesangial cell hypertrophy require NFAT4. J Biol Chem. 279: 20950-20958, 2004.

12. Garcia-Montero AC, Vasseur S, Giono LE, Canepa E, Moreno S, Dagorn JC and Iovanna JL: Transforming growth factor B-1 enhances Smad transcriptional activity through activation of $\mathrm{p} 8$ gene expression. Biochem J 357: 249-253, 2001.

13. Jiang WG, Davies G and Fodstad O: Com-1/p8 in oestrogen regulated growth of breast cancer cells, the ER- $\beta$ connection. Biochem Biophys Res Commun 330: 253-262, 2005.

14. Larrouy D, Vidal H, Andreelli F, Laville M and Langin D: Cloning and mRNA tissue distribution of human PPAR $\gamma$ coactivator-1. Int J Obesity 23: 1327-1332, 1999.

15. Knutti D, Kaul A and Kralli A: A tissue-specific coactivator of steroid receptors, identified in a functional genetic screen. Mol Cell Biol 20: 2411-2422, 2000.

16. Huss JM, Kopp RP and Kelly DP: Peroxisome proliferatoractivated receptor coactivator- $1 \alpha(\mathrm{PGC}-1 \alpha)$ coactivates the cardiac-enriched nuclear receptors estrogen-related receptor- $\alpha$ and $-\gamma$ - Identification of novel leucine-rich interaction motif within PGC-1 $\alpha$. J Biol Chem 277: 40265-40274, 2002.

17. Zhang Y, Castellani LW, Sinal CJ, Gonzalez FJ and Edwards PA: Peroxisome proliferator-activated receptor- $\gamma$ coactivator $1-\alpha$ (PGC-1- $\alpha$ ) regulates triglyceride metabolism by activation of the nuclear receptor FXR. Genes Dev 18: 157-169, 2004. 
18. Wu ZD, Puigserver P, Andersson U, Zhang CY, Adelmant G, Mootha V, Troy A, Cinti S, Lowell B, Scarpulla RC and Spiegelman BM: Mechanisms controlling mitochondrial biogenesis and respiration through the thermogenic coactivator PGC-1. Cell 98: 115-124, 1999.

19. Jiang WG, Davies D, Martin TA, Kynaston K, Mason MD and Fodstad O: COM-1/P8 (candidate of metastasis-1) acts as a putative tumour suppressor in prostate cancer. Int J Mol Med 18: 981-986, 2006.

20. Davies G, Jiang WG and Mason MD: Cell-cell adhesion and signalling intermediates in human prostate cancer. J Urol 163: 985-992, 2000

21. Jiang WG, Grimshaw D, Lane J, Martin TA, Parr C, Davies G, Laterra J, and Mansel RE: Retroviral hammerhead transgenes to cMET and HGF/SF inhibited growth of breast tumour, induced by fibroblasts. Clin Cancer Res 9: 4274-4281, 2003

22. Jiang WG, Hiscox S, Hallett MB, Horrobin DF, Mansel RE, and Puntis MCA: Regulation of the expression of E-cadherin on human cancer cells by $\gamma$ linolenic acid. Cancer Res 55: 5043-5048, 1995.

23. Puigserver P, Adelmant C, Wu ZD, Fan M, Xu JM, O'Malley B and Spiegelman BM: Activation of PPAR $\gamma$ coactivator-1 through transcription factor docking. Science 286: 1368-1371, 1999.

24. Herzig S, Long FX, Jhala US, Hedrick S, Quinn R, Bauer A, Rudolph D, Schutz G, Yoon C, Puigserver P, Spiegelman B and Montminy M: CREB regulates hepatic gluconeogenesis through the coactivator PGC-1. Nature 413: 179-183, 2001.

25. Louet JF, Hayhurst G, Gonzalez FJ, Girard J and Decaux JF: The coactivator PGC-1 is involved in the regulation of the liver carnitine palmitoyltransferase I gene expression by cAMP in combination with HNF4 $\alpha$ and cAMP-response element-binding protein (CREB). J Biol Chem 277: 37991-38000, 2002.

26. Michael LF, Wu ZD, Cheatham RB, Puigserver P, Adelmant G, Lehman JJ, Kelly DP and Spiegelman BM: Restoration of insulin-sensitive glucose transporter (GLUT4) gene expression in muscle cells by the transcriptional coactivator PGC-1. Proc Natl Acad Sci USA 98: 3820-3825, 2001.

27. Oberkofler H, Esterbauer H, Linnemayr V, Strosberg AD Krempler F and Patsch W: Peroxisome proliferator-activated receptor (PPAR) $\gamma$ coactivator-1 recruitment regulates PPAR subtype specificity. J Biol Chem 277: 16750-16757, 2002.

28. Delerive P, Wu YF, Burris TP, Chin WW and Suen CS: PGC-1 functions as a transcriptional coactivator for the retinoid $\mathrm{X}$ receptors. J Biol Chem 277: 3913-3917, 2002.

29. Puigserver P, Rhee J, Lin JD, Wu ZD, Yoon JC, Zhang CY, Krauss S, Mootha VK, Lowell BB and Spiegelman BM: Cytokine stimulation of energy expenditure through p38 MAP kinase activation of PPAR $\gamma$ coactivator-1. Mol Cell 8: 971-982, 2001.

30. Lin J, Wu H, Tarr PT, Zhang CY, Wu ZD, Boss O, Michael LF, Puigserver P, Isotani E, Olson EN, Lowell BB, Bassel-Duby R and Spiegelman BM: Transcriptional co-activator PGC-1 $\alpha$ drives the formation of slow-twitch muscle fibres. Nature 418: 797-801, 2002.

31. Lane RH, MacLennan NK, Hsu JL, Janke SM and Pham TD: Increased hepatic peroxisome proliferator-activated receptor- $\gamma$ coactivator-1 gene expression in a rat model of intrauterine growth retardation and subsequent insulin resistance. Endocrinology 143: 2486-2490, 2002.

32. Tcherepanova I, Puigserver P, Norris JD, Spiegelman BM and McDonnell DP: Modulation of estrogen receptor- $\alpha$ transcriptional activity by the coactivator PGC-1. J Biol Chem 275: $16302-16308,2000$.
33. Kressler D, Schreiber SN, Knutti D and Kralli A: The PGC-1related protein PERC is a selective coactivator of estrogen receptor $\alpha$. J Biol Chem 277: 13918-13925, 2002.

34. Cook SA, Matsui T, Li L and Rosenzweig A: Transcriptional effects of chronic Akt activation in the heart. J Biol Chem 277: 22528-22533, 2002.

35. Jiang WG, Douglas-Jones A and Mansel RE: Level of expression of PPAR- $\gamma$ and its co-activator (PPAR-GCA) in human breast cancer. Int J Cancer 106: 752-757, 2003.

36. Chang TH and Szabo E: Induction of differentiation and apoptosis by ligands of peroxisome proliferator-activated receptor $\gamma$ in non-small cell lung cancer. Cancer Res 60: 1129-1138, 2000.

37. Badawi AF and Badr MZ: Expression of cyclooxygenase- 2 and peroxisome proliferator activated recptor- $\gamma$ and levels of prostaglandin E2 and 15-deoxy-delta-12,14-prostaglandin $\mathrm{J} 2$ in human breast cancer and metastasis. Int J Cancer 103: 84-90, 2003.

38. Puigserver P, Wu ZD, Park CW, Graves R, Wright M and Spiegelman BM: A cold-inducible coactivator of nuclear receptors linked to adaptive thermogenesis. Cell 92: 829-839, 1998.

39. Castillo G, Brun RP, Rosenfield JK, Hauser S, Park CW, Troy AE, Wright ME and Spiegelman BM: An adipogenic cofactor bound by the differentiation domain of PPAR $\gamma$. EMBO J 18: 3676-3587, 1999.

40. Esterbauer H, Oberkofler H, Krempler F and Patsch W: Human peroxisome proliferator activated receptor $\gamma$ coactivator 1 (PPARGC1) gene: cDNA sequence, genomic organization, chromosomal localization, and tissue expression. Genomics 62: 98-102, 1999.

41. Hisatake J, Ikezoe T, Carey M, Holden S, Tomoyasu S and Koeffler HP: Down-regulation of prostate-specific antigen expression by ligands for peroxisome proliferator-activated receptor $\gamma$ in human prostate cancer. Cancer Res 60: 5494-5498, 2000

42. Jiang WG, Bryce RP and Horrobin DF: Essential fatty acids, the molecular and cellular mechanisms of their anticancer action and clinical implications. Crit Rev Oncol Haematol 27: 179-209, 1998.

43. Yoon JC, Puigserver P, Chen GX, Donovan J, Wu ZD, Rhee J, Adelmant G, Stafford J, Kahn CR, Granner DK, Newgard CB and Spiegelman BM: Control of hepatic gluconeogenesis through the transcriptional coactivator PGC-1. Nature 413: 131-138, 2001.

44. Feilchenfeldt J, Brundler MA, Soravia C, Totsch M and Meier CA: Peroxisome proliferator-activated receptors (PPARs) and associated transcription factors in colon cancer: reduced expression of PPAR $\gamma$-coactivator 1 (PGC-1). Cancer Lett 203: 25-33, 2004

45. Carracedo A, Lorente M, Egia A, Blazquez C, Garcia S, Giroux V, Malicet C, Villuendas R, Gironella M, Gonzalez-Feria L, Piris MA, Iovanna JL, Guzman M and Velasco G: The stress-regulated protein $\mathrm{p} 8$ mediates cannabinoid-induced apoptosis of tumor cells. Cancer Cell 9: 301-312, 2006.

46. Malicet C, Giroux V, Vasseur S, Dagorn JC, Neira JL and Iovanna JL: Regulation of apoptosis by the p8/prothymosin $\{\alpha\}$ complex. Proc Natl Acad Sci USA 103: 2671-2676, 2006. 